\title{
MELASMA SHOW UP IN CONTRACEPTIVE PILLS ACCEPTORS
}

\author{
Cahya Novenita Azzahra ${ }^{1 *}$, Widyawati ${ }^{2}$, Liza Afriliana ${ }^{2}$, Julian Dewantiningrum ${ }^{3}$ \\ ${ }^{1}$ Undergraduate Program, Faculty of Medicine, Diponegoro University, Semarang, Indonesia \\ ${ }^{2}$ Department of Dermatology and Venerology, Faculty of Medicine, Diponegoro University, Semarang, Indonesia \\ ${ }^{4}$ Department of Obstetrics and Gynecology, Faculty of Medicine, Diponegoro University, Semarang, Indonesia \\ *Corresponding author, E-mail : cahyanovenita@gmail.com
}

\begin{abstract}
Introduction : Melasma is one of the commonest hyperpigmentation disorders among women, found on face especially on sunlight exposured area. One of the factors causing melasma is the use of oral contraceptives which cause the buildup of the hormones estrogen and progesterone on the skin. Objectives : The aim of the study is to analyze the association between duration of contraceptive pills use and melasma. Methods : This is a cross sectional study, conducted from May to July 2020. Thirty six oral contraceptive acceptor aged 36-55 year old were included in this study. The data was collected primarily using questionnaires. And then researcher take the photo of face of the respondents. Physical examinations were done through observation with a photo of the respondents. The diagnosis of melasma was determined by the researcher. Physical examinations were done through observation with a photo of the respondents. Data analysis using the Chi Square test with a significance value $\mathrm{p}<0,05$. Results : Based on the results of this study, the significance less than 0.05 which indicates a relationship between variables duration of contraceptive pills use and melasma. Conclusions : This study shows a association between duration of contraceptive pills use and melasma
\end{abstract}

Keywords : melasma, contraceptive pills.

\section{INTRODUCTION}

Skin health is one of the most important things for a person, because it relates with physical appearance that reflect one's self confident. Changes in the skin occur with aging and several external factors, one of the skin change is hyperpigmentation disorder. Melasma reported to be the one of the most common hyperpigmentation disorders among womans. ${ }^{1,2}$

Melasma or khloasma is common hyperpigmentation patches which commonly found on face especially on sunlight exposured area. The clinical appearance of melasma presents light to dark brown macules with predilection area on cheeks, forehead, upper lip, nose, and chin. ${ }^{1,2}$ There is also extrafacial melasma that affecting the arms and neck, but extrafacial melasma has been rarely reported. ${ }^{1,2}$, ${ }^{3}$ Melasma more common on women than in men, especially on reproductive age and rarely reported before puberty age. ${ }^{2,4}$ According to the distribution, melasma lession can be categorized into three patterns include a centrofacial that affects on cheeks, forehead, nose, upper lip, and chin, malar that affects on cheeks and nose, and mandibular that affects on mandibular ramus. ${ }^{1,4}$

An epidemiology study reported that melasma commonly happen in country with high intensity of ultraviolet exposure like East Asia
(Japan, Korea, China), India, Pakistan, and America especially Brazil. According to Fitzpatrick's skin phototype, Indonesian has skin type IV-V that have a risk to have melasma ${ }^{4}$

Etiopathogenesis of melasma is poorly understood, but there are multifactorial factors include ultraviolet exposures, genetic predispotition, pregnancy, uses of oral contraceptive, cosmetic, phototoxic drugs, anticonvulsant drugs, and endocrine factors that related with thyroid disorders. 2, 4, 5 Oral contraceptive could cause melasma because of the buildup of the hormones estrogen and progesterone on the skin. ${ }^{6}$ Common contraceptive pills that are often used are combination pils estrogen and progestin. Progestin is a synthesis progesteron that have a similar effects with original progesteron.

Melasma is one of side effects of the contraceptive pills use. Melasma happen because of the buildup of the hormones estrogen and progesteron on the skin. Estrogen affect the melanocytes and cause the pigmentation of skin, while progesteron affect to increase the distribution of melanin in the cells. Melasma show up after using oral contraceptive pill for one to three years. The previous study reported that estrogen and progesteron play a role for melasma. Melasma is worrisome and affect the quality of life of a women, nevertheles, women 
facing a dilemma because oral contraceptive pill give them regular cycle yet they also have to deal some of unpleasant effect by using it. ${ }^{7}$ Based of the background, researcher is interested to prove whether the duration of contraceptive pills use is associated with the incidence of melasma in women.

\section{METHODS}

This study used a cross-sectional design. The research was conducted in May-July 2020 and held in Demak City, Central Java. The subjects were 36 womens aged 30-55 years old using oral contraceptive acceptors who meet inclussion criteria. The inclussion criteria are womens aged 30-55 years old, a contraceptive pills acceptor with the duration of uses less than to more that three years, and willingly to become respondent. The exclussion criteria are pregnant womens, have a thyroid disorders, have a family history of melasma, doing a hormonal estrogen and progesteron therapy, use a cosmetics or drugs that induced melasma, and frequently exposed to the sunlight.

The data was collected primarily using questionnaire. Respondents that qualify inclussion criteria and not eligible exclussion criteria will be done filling out the quissionaire. And then researcher take the photo of face of the respondents. When all done, physical examinations were done through observation with a photo of the respondents. The diagnosis of melasma was determined by the researcher.

The independent variable of this study is duration of contraceptive pills use. The dependent variable is incidence of melasma. Data analysis using the Chi Square test with a significance value $\mathrm{p}<0,05$.

\section{RESULTS}

Table 1. Characteristics of Respondents

\begin{tabular}{ccccccc}
\hline $\begin{array}{c}\text { Duration of } \\
\text { Contraceptive Pills } \\
\text { Use }\end{array}$ & \multicolumn{2}{c}{ Melasma } & \multicolumn{2}{c}{ Not Melasma } & \multicolumn{2}{c}{ Total } \\
\cline { 2 - 7 } & $\mathrm{n}$ & $\mathrm{P}(\%)$ & $\mathrm{n}$ & $\mathrm{P}(\%)$ & $\mathrm{n}$ & $\mathrm{P}(\%)$ \\
\hline$\leq 3$ years & 7 & $70 \%$ & 3 & $30 \%$ & 10 & $100 \%$ \\
\hline$>3$ years & 26 & $100 \%$ & 0 & $0 \%$ & 26 & $100 \%$ \\
\hline Total & 33 & $91,7 \%$ & 3 & $8,3 \%$ & 36 & $100 \%$ \\
\hline
\end{tabular}

Based of the table from 36 respondents, the respondents that have a duration of contraceptive pills uses $>3$ years are more than the $\leq 3$ years, with details the respondents that have a duration of contraceptive pills use $\leq 3$ years are 10 womens $(27,8 \%)$ dan the duration of contraceptive pills use > 3 years are 26 womens $(72,2 \%)$.

Based on the data above, this study shows that from 10 womens with the duration of contraceptive pills use $\leq 3$ years, there are 7 respondents $(70 \%)$ with melasma dan 3 respondents $(30 \%)$ with no melasma. While from the 26 respondents with the duration of contraceptive pills use $>3$ years, all of the respondents $(100 \%)$ have melasma. Based on the data, we can conclude that there are 33 respondents $(91,7 \%)$ with melasma and 3 respondents $(8,3 \%)$ with no melasma

Table 2. The Association Between Duration of Contraceptive Pills Use and Melasma.

\begin{tabular}{cccccccc}
\hline $\begin{array}{c}\text { Duration of } \\
\text { Contraceptive } \\
\text { Pills Use }\end{array}$ & \multicolumn{2}{c}{ Melasma } & \multicolumn{2}{c}{ Not Melasma } & p & CI \\
\cline { 2 - 5 }$\leq \mathbf{3}$ years & 7 & $70 \%$ & 3 & $30 \%$ & & \\
\hline$>$ 3 years & 26 & $100 \%$ & 0 & $0 \%$ & & $0,017 *$ & $0,467-1,050$ \\
\cline { 1 - 5 } Total & 33 & $91,7 \%$ & 3 & $8,3 \%$ & &
\end{tabular}

*: Significance $(\mathrm{p}<0,05)$ 
Based on the table 2, there are 33 respondents $(91,7 \%)$ have melasma. From all of the respondents that have melasma, 26 from 33 respondents that have melasma, they have used the contraceptive pills more than 3 years (> 3 years), and from the Chi Square test, got the significance value $<0,05$ or $\mathrm{p}<0,05$ which means that there is an association between duration of contraceptive pills use and melasma.

\section{DISCUSSION}

This study show that there is an association between the duration of contraceptive pills use and melasma. This result is the same with study from Mahdalena, and friends from Dermatology and Venerology Department, Faculty of Medicine, Sumatera Utara University, that melasma will show up on the duration of contraceptive pills use more than 36 months or more than 3 years with percentage $58,9 \%{ }^{8}$ Similar result was found from Dina Sulviana and friends which reported that contraceptive pills acceptors that use contraceptive pills more than 1 year more often have a melasma than the contraceptive pills acceptors that use contraceptive pills less than 1 year. ${ }^{9}$

This result accordance with the theoretical basis, that longer use of contraceptive pills will increase the incidence of melasma through several mechanism, such as estradiol that play a role on increace the MCR 1 (melanocortin receptor-1) on melanocytes, tyronase level, and mRNA level. ${ }^{10,11}$ Tyronase enzyme play a role in the catalytic reaction, change the tyrosine become L3,4 DOPA (dihydroxyphenilalanine), the increase of tyronase will affect the melanin formation to become more and more. Melanogenesis start with oxidation of aminotyrosine acid become $L$ dihidroksifenilalanin (L- DOPA) and then become dopaquinone. This step accelerated with the help of tyronase enzyme. The next process is polimeration from dopaquinone become melanin. Estrogen will affect melanogenesis, estrogen induce the synthesis of melanogenic enzyme such as tyronase, tyrosinase- related protein- 1 (Trp1), and Trp-2 also the activities of tyronase on the development of melanocytes. If there is an increase of estrogen or progesteron level in the body so that will affect acceleration of melanogenesis. ${ }^{7,} 8,12,13$
Another mechanism is estrogen play a role to induce the growth of basal keratinocytes then will effects the proliferation of melanocytes, and tranfer of melanosomes that cause melasma. Melanosomes sythesized by melanocytes, melanosomes consist of cocoa bio-chroma that is melanin. Melanosomes hidrolyzed by enzymes with varying speeds. Keratinocytes will determine the amount of melanin and skin color. Estrogen also reported play a role on produce KGF (keratinocyte growth factor). KGF will induce the transfer of melanosomes to keratinocytes. Keratinocytes set the adhession, morfology, and the survival of melanocytes. Exaggerated of sunlight exposure, use of drugs, and hormon especially estrogen and progesteron will affect the anterior pituitary to produce MSH (Melanin Stimulating Hormone) that will affect on hyperpigmentation on the skin. ${ }^{9}, 10,14$ Because of that, the more melanocytes so the more production of melanin. ${ }^{15}$

The increased progesteron concentration will increase keratinocytes proliferation. Progesteron also increase the amount of melanocytes and increase the tyronase activities on melanocytes. There are many progesteron receptors found on the epidermis that effects melanocytes. ${ }^{10}$ Progesteron will also increase the distribution of melanin on the hyperpigmentation cells on melasma. ${ }^{7,8}$

The limitations of this study is due to the outbreak of Corona Virus Disease-19 (COVID19), physical observation could not be done directly so that researcher only depend on the quality of photograph taken by respondent. Also this study only use respondent with oral hormonal contraceptives only.

\section{CONCLUSION}

Based on the result and discussion, concluded that:

1) There is an assosiation between duration of contraceptive pills use and melasma.

2) The longer the use of contraceptive pills, the more incidence of melasma on women-

\section{REFERENCES}

1. Serena NB, Bruce Smoller G. An Overview on Melasma. J Pigment Disord. 2015;2(10). doi:10.4172/2376-0427.1000216 
2. Ogbechie-Godec OA, Elbuluk N. Melasma: an Up-to-Date Comprehensive Review. Dermatol Ther (Heidelb). 2017;7(3):305318. doi:10.1007/s13555-017-0194-1

3. Putri WE, Kurniawati Y, Djauhari T. Depigmenting Agent Melanotoksik Pada Pengobatan Melasma. Med Heal Sci J. 2018;2(2). doi:10.33086/mhsj.v2i2.584

4. Handel AC, Miot LDB, Miot HA. Melasma: A clinical and epidemiological review. $A n$ Bras Dermatol. 2014;89(5):771-782. doi:10.1590/abd1806-4841.20143063

5. Passeron T, Picardo M. Melasma, a photoaging disorder. Pigment Cell Melanoma Res. 2018;31(4):461-465. doi:10.1111/pcmr.12684

6. WHO. Rekomendasi Praktik Terpilih pada Penggunaan Kontrasepsi. 2016:72. http://www.searo.who.int/indonesia/topics/s elected_practice_recommendations_for_con traceptive_use.pdf.

7. Astutik DWI. Kontrasepsi Hormonal Suntik Dan Pil Kombinasi Di Bpm. J Issues Midwifery. 2019;2(November 2018):17-29.

8. Mahdalena I, Jusuf NK, Putra IB. Melasma characteristic in hormonal contraceptive acceptors at Kelurahan Mangga Kecamatan Medan Tuntungan, Medan-Indonesia. Bali Med J. 2018;7(3):645-649. doi:10.15562/bmj.v7i3.1000

9. Damayanti SD, Pratiwi IP, Petrica G. International Conference on Applied Science and Health 2017 CONTRACEPTION WITH THE INCIDENCE OF MELASMA IN
International Conference on Applied Science and Health 2017. Icash-a57. 2017;(2012):223-227.

10. Cario M. How hormones may modulate human skin pigmentation in melasma: An in vitro perspective. Exp Dermatol. 2019;28(6):709-718. doi:10.1111/exd.13915

11. Kumre K, Varma K, Sharma H, Singh U. Study of Hormonal Profile in Female Melasma Patients in a Tertiary Care Hospital. $J$ Evol Med Dent Sci. 2016;5(31):1663-1666. doi:10.14260/jemds/2016/392

12. Suryaningsih BE, Soebono H. Biologi Melanosit. Tinj Pustaka, MDVI. 2016;43(2):78-82.

13. D'Mello SAN, Finlay GJ, Baguley BC, Askarian-Amiri ME. Signaling pathways in melanogenesis. Int J Mol Sci. 2016;17(7):118. doi:10.3390/ijms 17071144

14. Duval C, Chagnoleau C, Pouradier F, Sextius P, Condom E, Bernerd F. Human skin model containing melanocytes: Essential role of keratinocyte growth factor for constitutive pigmentation-functional response to $\alpha$-melanocyte stimulating hormone and forskolin. Tissue Eng - Part C Methods. 2012;18(12):947-957. doi:10.1089/ten.tec.2011.0676

15. Cichorek M, Wachulska M, Stasiewicz A, Tymińska A. Skin melanocytes: Biology and development. Postep Dermatologii $i$ Alergol. 2013;30(1):30-41. doi:10.5114/pdia.2013.33376 